\title{
PRZESTRZENNE ZRÓŻNICOWANIE SYTUACJI SPOŁECZNO-GOSPODARCZEJ A EFEKTYWNOŚĆ ZATRUDNIENIOWA W POWIATOWYCH URZĘDACH PRACY W POLSCE
}

\section{THE SPATIAL DIVERSITY OF SOCIO-ECONOMIC SITUATION AND THE EMPLOYEE EFFICIENCY IN DISTRICT LABOR OFFICE IN POLAND}

\author{
Katedra Zastosowań Matematyki w Ekonomii, Zachodniopomorski Uniwersytet Technologiczny \\ w Szczecinie, ul. Klemensa Janickiego 31, 71-270 Szczecin, ORCID: 0000-0001-8959-7269 \\ e-mail: Iwona.bak@zut.edu.pl \\ ${ }^{1}$ Katedra Zastosowań Matematyki w Ekonomii, Zachodniopomorski Uniwersytet Technologiczny \\ w Szczecinie, ul. Klemensa Janickiego 31, 71-270 Szczecin, ORCID: 0000-0003-4161-3877 \\ e-mail: Katarzyna.wawrzyniak@zut.edu.pl \\ ${ }^{2}$ Stowarzyszenie Czas Przestrzeń Tożsamość, ul. Lwowska 3/1, 71-027 Szczecin \\ ORCID: 0000-0001-7835-7104
}

\begin{abstract}
Summary. District Labor Offices (PUP) are trying to restore unemployed to the open labor market by using active forms of activating them. Each PUP has in its package of activities the so-called active forms of counteracting unemployment. These include, among others, internships, trainings, intervention works, public works, co-financing of starting business activity, reimbursement of equipment costs and retrofitting of the workplace. To introduce the unemployed to the labor market, a labor office uses one or several of the above-mentioned forms of activation. The activities of PUPs in the area of customer activation are subject to annual evaluation. The basic problem of people who supervise the results of labor offices at the poviat, regional and national level is the answer to the question what factors may affect the effectiveness of PUPs. In the article was tried to identify regularities in the scope of dependence between employment effectiveness in PUPs and factors characterizing the socio-economic situation of area, where their operate. The survey was based on data from 2016 and covered all PUPs.
\end{abstract}

Słowa kluczowe: efektywność zatrudnieniowa, powiatowe urzędy pracy, rynek pracy, sytuacja społeczno-gospodarcza.

Key words: employment efficiency, District Labor Offices, labor market, socio-economic situation.

\section{WSTĘP}

Powiatowe urzędy pracy (PUP), stosując aktywne formy aktywizacji osób bezrobotnych, starają się przywrócić je na otwarty rynek pracy. Samorząd powiatowy poprzez PUP-y, wchodzące w skład powiatowej administracji zespolonej, wykonuje zadania związane z obsługą osób bezrobotnych, obsługą pracodawców poszukujących pracowników, analizami rynku pracy oraz prowadzi inne działania z nim związane. W miastach na prawach powiatu (powiat grodzki) działalność urzędu obejmuje jedno miasto, a w przypadku powiatów ziemskich - kilka lub kilkanaście gmin. Każdy urząd pracy posiada w swoim pakiecie działań tzw. aktywne formy przeciwdziałania bezrobociu. Zgodnie z ustawą z dnia 20 kwietnia 2004 r. 
o promocji zatrudnienia i instytucjach rynku pracy (art. 35, ust. 1, art. 44) do podstawowych form aktywności zatrudnieniowej należą: staże, szkolenia, prace interwencyjne, roboty publiczne, dofinansowanie do podejmowania działalności gospodarczej, refundacja kosztów wyposażenia i doposażenia stanowiska pracy. Te formy aktywizacji stanowią podstawę obliczania wskaźników efektywności zatrudnieniowej i kosztowej, których wartości decydują o ocenie sprawności funkcjonowania PUP-ów. Ta ocena jest na tyle istotna, że w licznych opracowaniach (raportach) przedstawiane były zarówno aspekty organizacyjno-prawne, jak i aspekty metodologiczne związane z pomiarem efektywności usług i instrumentów rynku pracy w Polsce (Błędowski 2008; Efektywność polityki rynku... 2011; Metody i narzędzia... 2012; Analiza rozwiązań... 2017).

Urząd pracy, wprowadzając na rynek pracy osoby bezrobotne, wykorzystuje jedną formę lub kilka ww. form aktywizacji. Działania PUP-ów w zakresie aktywizacji klientów podlegają corocznej ocenie. Do tej pory efektywność urzędu była obliczana w taki sposób, że badano, ile osób po zastosowaniu danej formy aktywizacji pozostawało w określonym czasie w rejestrze osób odprowadzających składkę na ubezpieczenie społeczne, przy czym większa liczba osób, odnotowanych w systemie Zakładu Ubezpieczeń Społecznych jako płatnicy świadczyła o lepszej pracy urzędu. Podstawowym problemem osób nadzorujących rezultaty działalności urzędów pracy, na poziomie powiatu, regionu i kraju, jest identyfikacja czynników mogących wpływać na efektywność zatrudnieniową w PUP-ach.

Celem badań zaprezentowanych $\mathrm{w}$ artykule było zidentyfikowanie wpływu sytuacji społeczno-gospodarczej na efektywność zatrudnieniową uzyskiwaną w powiatowych urzędach pracy. Badaniem objęto wszystkie PUP-y funkcjonujące w Polsce w 2016 roku, a prawidłowości w zakresie zależności pomiędzy efektywnością zatrudnieniową w PUP-ach a sytuacją społeczno-gospodarczą poszukiwano na poziomie województw. ${ }^{1}$

\section{BADANIA CATI}

W pierwszym etapie badań, w celu identyfikacji czynników wpływających na efektywność zatrudnieniową PUP-ów w Polsce, skorzystano z opinii ekspertów, które zaczerpnięto z badania zrealizowanego w ramach projektu „Wypracowanie metodologii i wdrożenie monitorowania efektywności zatrudnieniowej podstawowych form aktywizacji zawodowej bezrobotnych w okresie dłuższym niż 12 miesięcy od zakończenia działań urzędu pracy". Jednym z celów tego badania było określenie czynników wpływających na efektywność aktywizacji zawodowej prowadzonej przez PUP-y. Badanie zrealizowane zostało z wykorzystaniem techniki CATI (wspomagany komputerowo wywiad telefoniczny); zakresem swoim objęło całą zbiorowość, czyli 340 PUP-ów. Z założenia wywiady przeprowadzano z dyrektorami urzędów lub z osobami przez nich wyznaczonymi. Otrzymano łącznie 260 wywiadów efektywnych, co stanowi $76 \%$ powiatowych urzędów pracy w Polsce (Badanie ilościowe... 2018).

\footnotetext{
${ }^{1}$ Analizę zróżnicowania efektywności zatrudnieniowej według województw podali m.in. Reichelt (2007); Cicha-Nazarczuk (2015); Knapińska (2015).
} 
Wśród czynników, najczęściej wskazanych przez pracowników PUP-ów jako wpływających na efektywność zatrudnieniową, znalazły się m.in.

- czynniki związane z usytuowaniem powiatu. Zdaniem respondentów największy pozytywny wpływ na efektywność zatrudnieniową mają: rozwinięta sieć drogowa w powiecie $(77,69 \%)$, fakt działania na terenie miasta na prawach powiatu $(76,54 \%)$ oraz fakt działania w powiecie, który sąsiaduje $z$ dużym miastem $(75,00 \%)$; podane wartości procentowe stanowią sumę odpowiedzi „wpływ pozytywny” i „wpływ zdecydowanie pozytywny”;

- czynniki związane z charakterystyką lokalnego rynku pracy. Respondenci najlepiej oceniali: dużą liczbę firm usługowych w powiecie $(90,77 \%)$, dużą liczbę zakładów przemysłowych (84,62\%), dużą liczbę podmiotów publicznych, bez szkolnictwa $(83,08 \%)$, dużą liczbę średnich podmiotów gospodarczych $(82,31 \%)$ oraz dobrą dostępność oferty szkoleniowej $(81,15 \%)$;

- czynniki związane z lokalną sytuacją społeczną. Ankietowani najczęściej pozytywnie oceniali: wysoką motywację uczestników aktywizacji (66,54\%), odpowiednią liczbę pracowników PUP pracujących bezpośrednio z bezrobotnymi $(63,08 \%)$ oraz współpracę z Ośrodkiem Wsparcia Ekonomii Społecznej (61,92\%). Wśród czynników wpływających negatywnie najczęściej wskazywano wysoki poziom przestępczości w powiecie $(58,08 \%)$ i niski poziom wykształcenia uczestników aktywizacji (43,46\%).

Uzupełnieniem badań CATI były jakościowe badania IDI (indywidualny wywiad pogłębiony) i FGI (grupowy wywiad pogłębiony) z przedstawicielami różnego rodzaju podmiotów zaangażowanymi w pracę urzędów pracy. Wyniki tych badań pozwoliły na dokonanie preselekcji czynników do kolejnych prac analitycznych.

\section{MATERIAt I METODA}

Badaną zbiorowość stanowiło 340 powiatowych urzędów pracy funkcjonujących w Polsce w 2016 roku, z czego: 26 PUP-ów działało na terenie powiatów grodzkich, 39 - na terenie powiatów ziemskich i grodzkich, a 275 - na terenie powiatów ziemskich². Informacje dotyczące wskaźnika efektywności zatrudnieniowej ${ }^{3}$ dla poszczególnych PUP-ów zaczerpnięto z publikacji Ministerstwa Rodziny, Pracy i Polityki Społecznej (Efektywność... 2017). Natomiast dane statystyczne dotyczące cech charakteryzujących sytuację społeczno-gospodarczą na terenach funkcjonowania PUP-ów pochodzą z Banku Danych Lokalnych GUS ${ }^{4}$. Cechy te pogrupowano w cztery obszary: bezrobocie, demografię, otoczenie, podmioty, a ich nazwy wraz z określeniem ich charakteru ${ }^{5}$ podano w tab. 1.

\footnotetext{
${ }^{2}$ Powiat ziemski obejmuje na ogół kilka gmin, na które składają się tereny wiejskie i mniejsze miasta. Natomiast powiat grodzki to inaczej miasto na prawach powiatu.

${ }^{3}$ Wskaźnik efektywności zatrudnieniowej podstawowych form aktywizacji zawodowej oznacza udział procentowy liczby osób, które w trakcie lub po zakończeniu udziału w podstawowych formach aktywizacji zawodowej zostały wykazane jako zatrudnione, w stosunku do liczby osób, które zakończyły udział w podstawowych formach aktywizacji zawodowej (Ustawa z dnia 20 kwietnia 2004 r. o promocji zatrudnienia..., art. 4, ust. 11', pkt 2b).

${ }^{4}$ Wartości cech diagnostycznych dotyczące 39 PUP-ów, funkcjonujących na terenie powiatów ziemskich i grodzkich, uzyskano poprzez agregację odpowiednich danych dotyczących badanych terenów.

${ }^{5} \mathrm{~W}$ zbiorze cech diagnostycznych znalazły się zarówno stymulanty, których duże wartości są korzystne dla istoty analizowanego zjawiska, jak i destymulanty, w przypadku których pożądane są wartości małe.
} 
Tabela 1. Nazwy i charakter cech diagnostycznych wykorzystanych w badaniu

\begin{tabular}{|c|c|c|}
\hline Obszar & Cecha diagnostyczna & $\begin{array}{l}\text { Charakter } \\
\text { cechy }\end{array}$ \\
\hline \multirow{11}{*}{ Bezrobocie } & $\begin{array}{l}X_{1}-\text { udział bezrobotnych z wykształceniem wyższym w ogólnej liczbie } \\
\text { bezrobotnych [\%] }\end{array}$ & \multirow{10}{*}{ destymulanty } \\
\hline & $\begin{array}{l}X_{2}-\text { udział bezrobotnych } \mathrm{z} \text { wykształceniem wyższym w liczbie ludności } \\
\text { w wieku produkcyjnym [\%] }\end{array}$ & \\
\hline & $\begin{array}{l}X_{3}-\text { udział młodych bezrobotnych (24 lata i mniej) w ogólnej liczbie } \\
\text { bezrobotnych [\%] }\end{array}$ & \\
\hline & $\begin{array}{l}X_{4}-\text { udział bezrobotnych w wieku } 24 \text { i mniej w liczbie ludności w wieku } \\
\text { produkcyjnym [\%] }\end{array}$ & \\
\hline & $\begin{array}{l}X_{5}-\text { udział bezrobotnych w czasie dłuższym niż } 12 \text { miesięcy w ogólnej liczbie } \\
\text { bezro-botnych [\%] }\end{array}$ & \\
\hline & $\begin{array}{l}X_{6}-\text { udział bezrobotnych w okresie } 12 \text { do } 24 \text { miesięcy w ogólnej liczbie } \\
\text { bezrobotnych [\%] }\end{array}$ & \\
\hline & $\begin{array}{l}X_{7}-\text { udział bezrobotnych w czasie dłuższym niż } 24 \text { miesięcy w ogólnej liczbie } \\
\text { bezrobotnych [\%] }\end{array}$ & \\
\hline & $X_{8}-$ udział bezrobotnych kobiet w ogólnej liczbie bezrobotnych [\%] & \\
\hline & $X_{9}$ - liczba bezrobotnych na 100 osób w wieku produkcyjnym & \\
\hline & $X_{10}$ - stopa bezrobocia rejestrowanego [\%] & \\
\hline & $X_{11}$ - liczba ofert pracy na 100 bezrobotnych & stymulanta \\
\hline \multirow{6}{*}{ Demografia } & $\begin{array}{l}X_{12} \text { - liczba osób w wieku poprodukcyjnym na } 100 \text { osób w wieku pro- } \\
\text { dukcyjnym }\end{array}$ & \multirow{4}{*}{ destymulanty } \\
\hline & $\begin{array}{l}X_{13} \text { - liczba osób w wieku przedprodukcyjnym na } 100 \text { osób w wieku pro- } \\
\text { dukcyjnym }\end{array}$ & \\
\hline & $\begin{array}{l}X_{14} \text { - liczba osób w wieku poprodukcyjnym do liczby osób w wieku przed- } \\
\text { produkcyjnym }\end{array}$ & \\
\hline & $X_{15}-$ udział ludności w wieku poprodukcyjnym w ludności ogółem [\%] & \\
\hline & $X_{16}$ - udział ludności w wieku przedprodukcyjnym w ludności ogółem [\%] & \multirow{2}{*}{ Stymulanty } \\
\hline & $X_{17}$ - udział ludności w wieku produkcyjnym w ludności ogółem [\%] & \\
\hline \multirow{13}{*}{ Otoczenie } & $X_{18}$ - przestępstwa stwierdzone przez Policję ogółem na 1000 mieszkańców & Destymulanta \\
\hline & $X_{19}$ - liczba szkół o niskich kwalifikacjacha na 10 tys. mieszkańców & \multirow{12}{*}{ stymulanty } \\
\hline & $\begin{array}{l}X_{20}-\text { liczba absolwentów szkół o niskich kwalifikacjach na } 10 \text { tys. miesz- } \\
\text { kańców }\end{array}$ & \\
\hline & $X_{21}$ - liczba szkół o wysokich kwalifikacjach ${ }^{b}$ na 100 tys. mieszkańców & \\
\hline & $\begin{array}{l}\text { X22- liczba absolwentów szkół o wysokich kwalifikacjach na } 10 \text { tys. miesz- } \\
\text { kańców }\end{array}$ & \\
\hline & $X_{23}-$ liczba instytucji szkoleniowych na 10 tys. mieszkańców ${ }^{c}$ & \\
\hline & $\begin{array}{l}X_{24}-\text { liczba pracujących w podmiotach powyżej } 9 \text { osób do liczby ludność } \\
\text { ogółem } \times 100 \%\end{array}$ & \\
\hline & $\begin{array}{l}X_{25} \text { - liczba pracujących w podmiotach powyżej } 9 \text { osób do liczby ludności } \\
\text { w wieku produkcyjnym } \times 100 \%\end{array}$ & \\
\hline & $X_{26}$ - szacunkowa liczba pracujących ${ }^{d}$ do liczby ludność ogółem $\times 100 \%$ & \\
\hline & $\begin{array}{c}X_{27} \text { - szacunkowa liczba pracujących do liczby ludności w wieku pro- } \\
\text { dukcyjnym } \times 100 \%\end{array}$ & \\
\hline & $X_{28}$ - drogi gminne i powiatowe o twardej nawierzchni na $100 \mathrm{~km}^{2}$ & \\
\hline & $X_{29}$ - podatki od osób fizycznych na 1 mieszkańca [zł] & \\
\hline & $X_{30}$ - podatki od osób prawnych na 1 mieszkańca [zł] & \\
\hline \multirow{4}{*}{ Podmioty } & $X_{31}$ - podmioty wpisane do rejestru REGON na 10 tys. Iudności & \multirow{4}{*}{ stymulanty } \\
\hline & $\begin{array}{l}X_{32}-\text { liczba podmiotów gospodarki narodowej ogółem na } 10 \text { tys. ludności } \\
\text { w wieku produkcyjnym }\end{array}$ & \\
\hline & $\begin{array}{l}X_{33} \text { - liczba podmiotów zatrudniających 0-9 osób na } 10 \text { tys. ludności w wieku } \\
\text { produkcyjnym }\end{array}$ & \\
\hline & $\begin{array}{l}X_{34}-\text { liczba podmiotów zatrudniających } 10-49 \text { osób na } 10 \text { tys. ludności w wieku } \\
\text { produkcyjnym }\end{array}$ & \\
\hline
\end{tabular}


Tabela 1. Nazwy i charakter cech diagnostycznych wykorzystanych w badaniu (cd.)

\begin{tabular}{|c|c|c|}
\hline Obszar & Cecha diagnostyczna & $\begin{array}{l}\text { Charakter } \\
\text { cechy }\end{array}$ \\
\hline & $\begin{array}{l}X_{35} \text { - liczba podmiotów zatrudniających } 50-249 \text { osób na } 10 \text { tys. ludności } \\
\text { w wieku produkcyjnym }\end{array}$ & \\
\hline & $\begin{array}{l}X_{36} \text { - liczba podmiotów zatrudniających } 250 \text { osób i więcej na } 10 \text { tys. ludności } \\
\text { w wieku produkcyjnym }\end{array}$ & \\
\hline & $\begin{array}{l}X_{37}-\text { liczba podmiotów sektora publicznego na } 10 \text { tys. ludności w wieku } \\
\text { produkcyjnym }\end{array}$ & \\
\hline & $\begin{array}{l}X_{38}-\text { liczba podmiotów sektora prywatnego na } 10 \text { tys. ludności w wieku } \\
\text { produkcyjnym }\end{array}$ & \\
\hline & $\begin{array}{l}X_{39}-\text { liczba podmiotów sektora: rolnictwo na } 10 \text { tys. ludności w wieku } \\
\text { produkcyjnym }\end{array}$ & \\
\hline & $\begin{array}{l}X_{40} \text { - liczba podmiotów sektora: przemysł i budownictwo na } 10 \text { tys. ludności } \\
\text { w wieku produkcyjnym }\end{array}$ & \\
\hline & 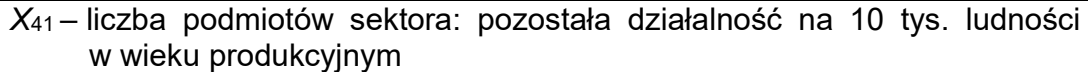 & \\
\hline
\end{tabular}

aSzkoły kształcące uczniów do czasu uzyskania matury, czyli szkoły: podstawowe, gimnazjalne, zasadnicze zawodowe, licea ogólnokształcące, średnie zawodowe.

${ }^{b}$ Szkoły kształcące uczniów po uzyskaniu matury, czyli szkoły policealne, wyższe.

cDane pochodzą z Rejestru instytucji szkoleniowych (www.ris.praca.gov.pl, dostęp: 20.09.2018).

dSzacunkowa liczba pracujących została obliczona w następujący sposób: liczba aktywnych zawodowo minus liczba zarejestrowanych bezrobotnych, przy czym liczbę aktywnych zawodowo obliczono jako ilorazu liczby bezrobotnych i stopy bezrobocia rejestrowanego, pomnożonego przez $100 \%$.

Badanie rozpoczęto od zredukowania zbioru cech diagnostycznych. W tym celu wykorzystano metodę parametryczną zaproponowaną przez Z. Hellwiga (Nowak 1990). Punktem wyjścia w tej metodzie jest macierz $\mathbf{R}$ zawierająca współczynniki korelacji pomiędzy poszczególnymi cechami diagnostycznymi. Kryterium klasyfikacji cech jest krytyczna (progowa) wartość współczynnika korelacji $r^{*}$, często przyjmowana arbitralnie na poziomie 0,5 (Nowak 1990; Panek 2009). W literaturze można również spotkać następujące podejścia do wyznaczania wartości progowej (Pociecha i in. 1988; Panek 2009):

- metodę minimaksową

$$
r^{*}=\min _{i} \max _{j}\left[r_{i j}\right]
$$

gdzie:

$r_{i j}$ - współczynniki korelacji Pearsona pomiędzy i-tą a j-tą potencjalną cechą diagnostyczną $(i, j=1,2, \ldots, k)$;

$k$ - liczba cech diagnostycznych

- procedurę weryfikacji istotności współczynnika korelacji

$$
r^{*}=\sqrt{\frac{t_{\alpha}^{2}}{t_{\alpha}^{2}+n-2}}
$$

gdzie:

$t_{\alpha}$ - wartość krytyczna rozkładu $t$ Studenta dla $n-2$ stopni swobody oraz dla z góry

ustalonego poziomu istotności $\alpha, n$ - liczebność próby.

Wartość progowa (krytyczna) wpływa na liczbę wybranych cech diagnostycznych. Im większa jest wartość progowa, tym więcej jest skupień, a tym samym więcej wybranych cech diagnostycznych. W przypadku małej wartości progowej zmniejsza się liczba skupień, a tym samym zmniejsza się liczba wybranych cech.

Cechy diagnostyczne ze względu na znaczny stopień skorelowania mogą tworzyć tzw. skupienia, czyli takie podzbiory zbioru cech, w których minimalne podobieństwo między cechami jest nie mniejsze od przyjętej arbitralnie wartości $r^{*}=0,5$ (Nowak 1990; Młodak 2006). Skupienia zawierają jedną tzw. cechę centralną oraz pewną liczbę tzw. cech 
satelitarnych ${ }^{6}$. Cechy nienależące do skupienia nazywają się cechami izolowanymi. Ostateczny zbiór cech diagnostycznych tworzą cechy centralne i izolowane. Algorytm znajdowania skupień cech z przyjętym a priori parametrem $r^{*}$ jest następujący:

1. W macierzy korelacji $\mathbf{R}$ znajduje się sumę elementów każdej kolumny (każdego wiersza):

$$
R_{l}=\sum_{k=1}^{L}\left|r_{k l}\right|
$$

gdzie:

$I$ - numer cechy w kolumnie $(I=1,2, \ldots, L)$,

$k$ - numer cechy w wierszu $(k=1,2, \ldots, L)$,

$L$ - liczba cech diagnostycznych,

$r_{k l}$ - współczynnik korelacji między $k$-tą a l-tą cechą diagnostyczną;

2. Wyszukuje się kolumnę o numerze $p$, dla której:

$R_{p}=\max _{l}\left\{R_{l}\right\}$

3. W danej kolumnie wyróżnia się elementy $r_{k p}$ spełniające nierówność:

$\left|r_{k p}\right| \geq r^{*}$

i odpowiadające tym elementom wiersze; cechę odpowiadającą wyróżnionej kolumnie uważa się za pierwszą cechę centralną, a cechy odpowiadające wyróżnionym wierszom za jej cechy satelitarne.

4. Z macierzy $\mathbf{R}$ skreśla się wyróżnione kolumny i wiersze, otrzymując tzw. zredukowaną macierz korelacji.

5. Postępowanie opisane w punktach 1-4 powtarza się, otrzymując dalsze skupienia i nową zredukowaną macierz korelacji; kontynuuje się dalszą procedurę aż do momentu wyczerpania zbioru cech.

Na podstawie zredukowanego zbioru cech diagnostycznych wyznaczono miarę syntetyczną z wykorzystaniem metody unitaryzacji zerowanej (Kukuła 2000) ${ }^{7}$. W metodzie tej stosuje się następujące przekształcenia rzeczywistych wartości wybranych cech:

- dla stymulant

$$
z_{i j}=\frac{x_{i j}-\min _{i} x_{i j}}{\max _{i} x_{i j}-\min _{i} x_{i j}}
$$

- dla destymulant

$$
z_{i j}=\frac{\max _{i} x_{i j}-x_{i j}}{\max _{i} x_{i j}-\min _{i} x_{i j}}
$$

gdzie:

$x_{i j}$ - wartość $j$-tej cechy diagnostycznej $w i$-tym obiekcie,

$\min _{i} x_{i j}$ - minimalna wartość $j$-tej cechy diagnostycznej,

$\max _{i} x_{i j}$ - maksymalna wartość j-tej cechy diagnostycznej,

$i=1,2, \ldots, n$,

$n$ - liczba obiektów,

${ }^{6}$ Cecha satelitarna to taka cecha, dla której korelacja z cechą centralną jest nie mniejsze niż $r^{\star}$.

${ }^{7} \mathrm{~W}$ pracy wykorzystano jedna z metod porządkowania liniowego, która często jest stosowana do klasyfikacji obiektów w badaniach społeczno-gospodarczych (por. np. Kukuła 2015; Kurzawa i in. 2017; Kurzawa i Łuczak 2017). 
$j=1,2, \ldots, k$,

$k-$ liczba cech diagnostycznych.

Taki sposób normalizacji powoduje, że wszystkie wartości znormalizowanych cech należą do przedziału $[0,1]$. Miarę syntetyczną $\left(z_{i}\right)$ oblicza się jako średnią arytmetyczną unormowanych wartości cech diagnostycznych:

$$
z_{i}=\frac{1}{k} \sum_{j=1}^{k} z_{i j}
$$

gdzie: $k$ - liczba cech diagnostycznych.

Miara syntetyczna $\left(z_{i}\right)$ przyjmuje wartości $z$ przedziału $[0,1]$. Im wartość $z_{i}$ jest bliżej jedności, tym sytuacja $i$-tego obiektu jest lepsza.

Na podstawie wartości miary syntetycznej można wyodrębnić cztery grupy typologiczne wykorzystując $\mathrm{np}$. metodę trzech średnich. Metoda ta polega na tym, że dla wszystkich badanych jednostek, uporządkowanych malejąco według wartości $z_{i}$, obliczamy średnią arytmetyczną $(\bar{z})$. Wyznaczona średnia $(\bar{z})$ dzieli zbiorowość na dwie grupy jednostek, przy czym w pierwszej grupie znajdują się jednostki o wartościach $z_{i}$ nie mniejszych od tej średniej $(\bar{z})$, a w grupie drugiej - jednostki o wartościach $z_{i}$ mniejszych od tej średniej $(\bar{z})$. Następnie w wydzielonych grupach jednostek ponownie oblicza się średnie, które dzielą zarówno pierwszą, jak i drugą grupę na kolejne dwie podgrupy jednostek. Średnie te możemy oznaczyć odpowiednio jako $\bar{z}_{1} \mathrm{i} \bar{z}_{2}$. W ten sposób otrzymujemy cztery grupy typologiczne obejmujące jednostki o wartościach miary $z_{i} z$ następujących przedziałów:

- grupa I (najlepsza): $z_{i} \geq \bar{z}_{1}$,

- grupa II: $\bar{z}_{1}>z_{i} \geq \bar{z}$

- grupa III: $\bar{z}>z_{i} \geq \bar{z}_{2}$,

- grupa IV (najgorsza): $z_{i}<\bar{z}_{2}$.

\section{WYNIKI}

W wyniku zastosowania parametrycznej metody Hellwiga pierwotny 41-elementowy zbiór cech diagnostycznych zredukowano do 16 cech. Ponieważ w badaniu przyjęto, że każdy obszar powinien być reprezentowany przynajmniej przez jedną cechę diagnostyczną, metodę parametryczną zastosowano odrębnie dla każdego obszaru i w ten sposób w zbiorze cech diagnostycznych znalazło się:

- sześć cech z obszaru bezrobocie

$X_{1}-$ udział bezrobotnych z wykształceniem wyższym w ogólnej liczbie bezrobotnych [\%],

$X_{3}$ - udział bezrobotnych w wieku 24 i mniej w ogólnej liczbie bezrobotnych [\%],

$X_{6}-$ udział bezrobotnych w czasie od 12 do 24 miesięcy w ogólnej liczbie bezrobotnych [\%],

$X_{8}-$ udział bezrobotnych kobiet w ogólnej liczbie bezrobotnych [\%],

$X_{9}$ - liczba bezrobotnych na 100 osób w wieku produkcyjnym,

$X_{11}$ - liczba ofert pracy na 100 bezrobotnych,

- jedna cecha z obszaru demografia

$X_{15}-$ udział ludności w wieku poprodukcyjnym w ludności ogółem [\%], 
- sześć cech z obszaru otoczenie:

$X_{18}$ - przestępstwa stwierdzone przez policję ogółem na 1000 mieszkańców,

$X_{19}$ - liczba szkół o niskich kwalifikacjach na 10 tys. mieszkańców,

$X_{20}$ - liczba absolwentów szkół o niskich kwalifikacjach na 10 tys. mieszkańców,

$X_{21}$ - liczba szkół o wysokich kwalifikacjach na 100 tys. mieszkańców,

$X_{25}$ - liczba pracujących w podmiotach zatrudniających ponad 9 osób do liczby ludności w wieku produkcyjnym $\times 100 \%$,

$X_{30}$ - podatki od osób prawnych na 1 mieszkańca [zł],

- trzy cechy z obszaru: podmioty

$X_{32}$-liczba podmiotów gospodarki narodowej ogółem na 10 tys. ludności w wieku produkcyjnym,

$X_{37}$ - liczba podmiotów sektora publicznego na 10 tys. ludności w wieku produkcyjnym,

$X_{39}$ - liczba podmiotów sektora rolnictwo na 10 tys. ludności w wieku produkcyjnym.

Dla przyjętych do badania cech wyznaczono miarę syntetyczną zgodnie z wzorem 8. Następnie metodą trzech średnich PUP-y przydzielono do czterech grup typologicznych. W tab. 2 zamieszczono rozkład liczby PUP-ów w województwach, z uwzględnieniem ich przynależności do poszczególnych grup.

Tabela 2. Rozkład liczby powiatowych urzędów pracy w Polsce w 2016 roku według województw i grup typologicznych

\begin{tabular}{|c|c|c|c|c|c|}
\hline \multirow[b]{2}{*}{ Województwo } & \multicolumn{4}{|c|}{ Liczba PUP-ów } & \multirow[b]{2}{*}{ Ogółem } \\
\hline & $\begin{array}{c}\text { grupa } 1 \\
z_{i} \geq 0,4129\end{array}$ & $\begin{array}{c}\text { grupa 2 } \\
0,4129>\mathrm{Zi}_{\mathrm{i}} \geq 0,3879\end{array}$ & $\begin{array}{c}\text { grupa 3 } \\
0,3879>z_{i} \geq 0,3657\end{array}$ & $\begin{array}{c}\text { grupa } 4 \\
Z_{i}<0,3657\end{array}$ & \\
\hline Dolnośląskie & 4 & 10 & 8 & 4 & 26 \\
\hline Kujawsko-pomorskie & 0 & 4 & 6 & 10 & 20 \\
\hline Lubelskie & 3 & 5 & 9 & 4 & 21 \\
\hline Lubuskie & 3 & 4 & 2 & 3 & 12 \\
\hline Łódzkie & 2 & 8 & 9 & 3 & 22 \\
\hline Małopolskie & 6 & 5 & 5 & 5 & 21 \\
\hline Mazowiecki & 12 & 10 & 10 & 7 & 39 \\
\hline Opolskie & 1 & 3 & 4 & 3 & 11 \\
\hline Podkarpackie & 3 & 9 & 5 & 4 & 21 \\
\hline Podlaskie & 1 & 3 & 7 & 3 & 14 \\
\hline Pomorskie & 2 & 6 & 5 & 4 & 17 \\
\hline Śląskie & 3 & 5 & 10 & 13 & 31 \\
\hline Świętokrzyskie & 1 & 4 & 5 & 4 & 14 \\
\hline Warmińsko-mazurskie & 5 & 3 & 7 & 5 & 20 \\
\hline Wielkopolskie & 16 & 8 & 6 & 1 & 31 \\
\hline Zachodniopomorskie & 3 & 8 & 5 & 4 & 20 \\
\hline Ogółem & 65 & 95 & 103 & 77 & 340 \\
\hline
\end{tabular}

Jak wynika z tab. 2, najwięcej PUP-ów znalazło się w trzeciej grupie typologicznej, a najmniej - w grupie pierwszej, charakteryzującej się największymi wartościami miary syntetycznej, czyli najlepszą sytuacją społeczno-gospodarczą. W tej grupie dominowały PUP-y z województw wielkopolskiego i mazowieckiego. Nie znalazł się w niej żaden PUP z województwa kujawsko-pomorskiego; w pozostałych województwach liczba PUP-ów należących do tej grupy kształtowała się w zakresie od 1 do 6 . W grupie czwartej, o najgorszej 
sytuacji społeczno-gospodarczej, znalazły się PUP-y z każdego województwa, przy czym najwięcej ich było z województw śląskiego i kujawsko-pomorskiego, a najmniej - z województwa wielkopolskiego.

$\mathrm{Na}$ podstawie tab. 2 sporządzono ranking województw, wykorzystując dwa kryteria. Pierwszym (głównym) kryterium był udział PUP-ów należących do 1. grupy typologicznej w ogólnej liczbie PUP-ów w danym województwie, a drugim - udział PUP-ów należących do grupy 4 . W tabeli 3 podano ranking województw uzyskany na podstawie malejących wartości wg kryterium pierwszego oraz rosnących wartości wg kryterium drugiego. Dla większości województw można było jednoznacznie określić miejsce w rankingu. Tylko w dwóch przypadkach powtórzyły się miejsca w rankingu zajmowane przez województwo; dotyczyło to województw warmińsko-mazurskiego i lubuskiego (miejsce w rankingu 4,5) oraz podkarpackiego i lubelskiego (miejsce w rankingu 8,5$)^{8}$.

Tabela 3. Ranking województw uzyskany na podstawie malejących udziałów PUP-ów należących do grupy 1. i rosnących udziałów PUP-ów należących do grupy 4. w ogólnej liczbie PUP-ów w danym województwie w 2016 roku

\begin{tabular}{|l|c|c|c|}
\hline \multicolumn{1}{|c|}{ Województwo } & $\begin{array}{c}\text { Udział PUP-ów należących } \\
\text { do grupy 1. w ogólnej liczbie } \\
\text { PUP-ów w danym } \\
\text { województwie [\%] }\end{array}$ & $\begin{array}{c}\text { Udział PUP-ów należących } \\
\text { do grupy 4. w ogólnej liczbie } \\
\text { PUP-ów w danym } \\
\text { województwie [\%] }\end{array}$ & $\begin{array}{c}\text { Miejsce } \\
\text { w rankingu }\end{array}$ \\
\hline Wielkopolskie & 51,6 & 3,2 & 1,0 \\
\hline Mazowieckie & 30,8 & 17,9 & 2,0 \\
\hline Małopolskie & 28,6 & 23,8 & 3,0 \\
\hline Warmińsko-mazurskie & 25,0 & 25,0 & 4,5 \\
\hline Lubuskie & 25,0 & 25,0 & 4,5 \\
\hline Dolnośląskie & 15,4 & 15,4 & 6,0 \\
\hline Zachodniopomorskie & 15,0 & 20,0 & 7,0 \\
\hline Podkarpackie & 14,3 & 19,0 & 8,5 \\
\hline Lubelskie & 14,3 & 19,0 & 10,0 \\
\hline Pomorskie & 11,8 & 23,5 & 11,0 \\
\hline Śląskie & 9,7 & 41,9 & 12,0 \\
\hline Łódzkie & 9,1 & 13,6 & 13,0 \\
\hline Opolskie & 9,1 & 27,3 & 14,0 \\
\hline Podlaskie & 7,1 & 21,4 & 15,0 \\
\hline Świętokrzyskie & 7,1 & 28,6 & 16,0 \\
\hline Kujawsko-pomorskie & 0,0 & 50,0 & \\
\hline
\end{tabular}

Źródło: opracowano na podstawie tab. 2.

Z badań CATI oraz indywidualnych i grupowych wywiadów pogłębionych wynika, że im lepsza jest sytuacja społeczno-gospodarcza na terenie funkcjonowania PUP-ów, tym łatwiej można uzyskać wyższą efektywność zatrudnieniową (Badanie ilościowe... 2018). W związku z tym, uwzględniając wyniki przedstawione w tab. 3, oczekiwano, że im wyższe będzie miejsce w rankingu województwa, tym wyższa powinna być efektywność zatrudnieniowa, czyli silniejsza dodatnia korelacja pomiędzy wskaźnikiem efektywności zatrudnieniowej, uzyskanej przez PUP-y w danym województwie, a wartością miary syntetycznej charakterryzującej sytuację społeczno-gospodarczą na terenie funkcjonowania PUP-ów.

\footnotetext{
${ }^{8}$ Miejsce w rankingu wyznaczono jako średnią arytmetyczną kolejnych pozycji przypadających na województwa; w przypadku województw warmińsko-mazurskiego i lubuskiego były to pozycje 4. i 5., a w przypadku województw podkarpackiego i lubelskiego - pozycje 8. i 9.
} 
W tabeli 4 zamieszczono współczynniki korelacji liniowej Pearsona ${ }^{9}$ pomiędzy efektywnością zatrudnieniową uzyskaną przez poszczególne PUP-y a miarą syntetyczną charakteryzującą sytuację społeczno-gospodarczą na terenie funkcjonowania PUP-ów. Jak wynika z tej tabeli, współczynnik korelacji między średnią wartością miary syntetycznej a efektywnością zatrudnieniową na poziomie województw wynosi 0,1441 , co oznacza bardzo słabą dodatnią zależność (Gruszczyński 1986). Świadczy to o tym, że dla danych zagregowanych nie uzyskano potwierdzenia faktu, że im lepsza jest sytuacja społeczno-gospodarcza w województwie, tym wyższa jest efektywność zatrudnieniowa. Rozpatrując każde z województw osobno, gdy współczynniki korelacji były obliczone na podstawie efektywności zatrudnieniowej i wartości $z_{i}$ dla poszczególnych PUP-ów należących do danego województwa, można już zaobserwować różne prawidłowości w zakresie współzależności pomiędzy analizowanymi zmiennymi:

- najsilniejsza dodatnia korelacja wystąpiła w województwach: łódzkim, warmińskomazurskim, małopolskim, podlaskim, wielkopolskim,

- brak korelacji zauważono w województwach: kujawsko-pomorskim, lubelskim, lubuskim, śląskim, świętokrzyskim,

- najsilniejsza ujemna korelacja wystąpiła w województwie zachodniopomorskim.

Tabela 4. Współczynniki korelacji między wskaźnikiem efektywności zatrudnieniowej $\left(E Z_{i}\right)$ a syntetyczną miarą $\left(z_{i}\right)$ dla PUP-ów funkcjonujących w poszczególnych województwach

\begin{tabular}{|c|c|c|c|}
\hline Województwo & $\begin{array}{c}\text { Współczynnik korelacji } \\
\text { między } E Z_{i} a z_{i}\end{array}$ & $\begin{array}{l}\text { Średnia wartość } z_{i} \\
\text { w województwach }\end{array}$ & $E Z_{w}$ w województwach ${ }^{a}$ \\
\hline Dolnośląskie & $-0,1240$ & 0,3913 & 80,39 \\
\hline Kujawsko-pomorskie & 0,0705 & 0,3696 & 76,38 \\
\hline Lubelskie & $-0,0619$ & 0,3839 & 79,68 \\
\hline Lubuskie & $-0,0559^{*}$ & 0,3967 & 78,79 \\
\hline Łódzkie & $0,3563^{*}$ & 0,3863 & 81,06 \\
\hline Małopolskie & $0,3169^{*}$ & 0,3873 & 75,89 \\
\hline Mazowieckie & 0,2234 & 0,3871 & 79,53 \\
\hline Opolskie & $0,1636^{*}$ & 0,3814 & 83,96 \\
\hline Podkarpackie & $0,2455^{*}$ & 0,3928 & 80,57 \\
\hline Podlaskie & 0,2909 & 0,3818 & 81,96 \\
\hline Pomorskie & 0,1687 & 0,3849 & 82,85 \\
\hline Śląskie & 0,0556 & 0,3727 & 75,78 \\
\hline Świętokrzyskie & 0,0574 & 0,3787 & 71,77 \\
\hline Warmińsko-mazurskie & $0,3474^{*}$ & 0,3877 & 75,92 \\
\hline Wielkopolskie & 0,2820 & 0,4111 & 80,77 \\
\hline Zachodniopomorskie & $-0,1624^{*}$ & 0,3887 & 79,22 \\
\hline
\end{tabular}

*współczynnik rang Spearmana; pozostałe współczynniki to współczynniki Pearsona.

a Informacje o wskaźniku efektywności zatrudnieniowej na poziomie województwa pochodzą z raportu Ministerstwa Rodziny, Pracy i Polityki Społecznej (Efektywność podstawowych form aktywizacji... 2017).

\section{WNIOSKI}

1. W przypadku danych zagregowanych na poziomie województwa (średnia wartość miary syntetycznej w województwie i wskaźnik efektywności zatrudnieniowej dla województwa) nie zaobserwowano wyraźnej zależności pomiędzy efektywnością zatrudnieniową a sytuacją

\footnotetext{
9Liniowość związku sprawdzono na podstawie diagramu korelacyjnego. W przypadku wątpliwości współczynnik korelacji liniowej Pearsona zastąpiono współczynnikiem rang Spearmana.
} 
społeczno-gospodarczą, o czym świadczy niski poziom współczynnika korelacji pomiędzy średnią wartością $\mathrm{z}_{\mathrm{i}}$ a wskaźnikiem efektywności zatrudnieniowej,

2. W przypadku dezagregacji danych, czyli po obliczeniu współczynników korelacji na podstawie miary syntetycznej i wskaźnika efektywności zatrudnieniowej dla poszczególnych powiatowych urzędów pracy, funkcjonujących na terenie danego województwa, zauważono następujące prawidłowości:

- w pięciu województwach współczynniki korelacji były dodatnie - na poziomie około 0,3, co oznacza wyraźną korelację o średnim natężeniu (Gruszczyński 1986) i świadczy o powiązaniu uzyskiwanego przez powiatowe urzędy pracy wskaźnika efektywności z sytuacją społeczno-gospodarczą na terenie ich funkcjonowania - dodatni kierunek tej zależności oznacza, że im lepsza jest sytuacja społeczno-gospodarcza, tym łatwiej można uzyskać wyższą efektywność;

- dla pozostałych województw nie uzyskano potwierdzenia o zależności pomiędzy sytuacją społeczno-gospodarczą a poziomem wskaźnika efektywności zatrudnieniowej (wartości bezwzględne współczynników korelacji nie przekroczyły 0,25);

- na uwagę zasługują te województwa, w przypadku których stwierdzono ujemną zależność pomiędzy analizowanymi zmiennymi - wymaga to pogłębionej analizy w celu wyjaśnienia przyczyn, dlaczego lepsza sytuacja na obszarze funkcjonowania PUP-ów skutkowała niższą efektywnością zatrudnieniową.

Celem badania było wykrycie zależności pomiędzy efektywnością zatrudnieniową, uzyskiwaną przez PUP-y, a sytuacją społeczno-gospodarczą na terenie ich funkcjonowania. Biorąc pod uwagę opinie ekspertów, oczekiwano, że im lepsza będzie sytuacja społeczno-gospodarcza, tym łatwiej można będzie wykazać się wyższym wskaźnikiem efektywności zatrudnieniowej. Przeprowadzone badania nie dały jednoznacznych wyników, co może wynikać np. z doboru cech diagnostycznych, a także ze sposobu pomiaru efektywności zatrudnieniowej.

\section{PIŚMIENNICTWO}

Analiza rozwiązań, o których mowa w art. 108 ust. $1 \mathrm{i}$ ustawy o promocji zatrudnienia $\mathrm{i}$ instytucjach rynku pracy. 2017. Warszawa, Ministerstwo Rodziny, Pracy i Polityki Społecznej Departament Funduszy Wydział Wydatków Fakultatywnych i Analiz Efektywności, https://www.mpips.gov.pl/ analizy-i-raporty/raporty-sprawozdania/rynek-pracy/, dostęp: 25.09.2018.

Badanie ilościowe w powiatowych urzędach pracy. 2018. Raport badawczy do projektu pt.: Wypracowanie metodologii i wdrożenie monitorowania efektywności zatrudnieniowej podstawowych form aktywizacji zawodowej bezrobotnych w okresie dłuższym niż 12 miesięcy od zakończenia działań urzędu pracy. Katowice, Stow. Czas Przestrzeń Tożsamość, Grupa BST Sp. z o.o.,.

Bank Danych Lokalnych, GUS, www.stat.gov.pl, dostęp: 20.09.2018.

Cicha-Nazarczuk M. 2015. Regionalne zróżnicowanie finansowania i efektywności aktywnej polityki rynku pracy w Polsce. Optimum. Stud. Ekon. UBiałyst. 4(76), 153-168.

Efektywność podstawowych form aktywizacji zawodowej, realizowanych w ramach programów na rzecz promocji zatrudnienia, łagodzenia skutków bezrobocia i aktywizacji zawodowej w 2016 roku. 2017. Warszawa, Ministerstwo Rodziny, Pracy i Polityki Społecznej, Departament Funduszy.

Efektywność polityki rynku pracy w Polsce. 2011. Red. Z. Wiśniewski, K. Zawadzki. Wojewódzki Urząd Pracy w Toruniu. Toruń, UMK. 
Efektywność usług i instrumentów rynku pracy służących podnoszeniu kwalifikacji bezrobotnych w Polsce i wybranych krajach Unii Europejskiej. 2008. Red. P. Błędowski. Warszawa, Ministerstwo Pracy i Polityki Społecznej, Departament Rynku.

Gruszczyński L.A. 1986. Elementy statystyki dla socjologów. Katowice, UŚl., 168.

Knapińska M. 2015. Efektywność polityki rynku pracy - aspekty teoretyczne i praktyczne. Pr. Nauk. UE Wroc., Ekonomia, 401, 187-197.

Kukuła K. 2000. Metoda unitaryzacji zerowanej. Warszawa, PWN, 60-92.

Kukuła K. 2015. Wykorzystanie analizy wielowymiarowej do badania zróżnicowania potencjału innowacyjnego Polski. Met. llościowe Bad. Ekon. 16(3), 194-201.

Kurzawa I, Łuczak A. 2017. Ocena poziomu zróżnicowanego rozwoju powiatów w Polsce z wykorzystaniem metod taksonomicznych. Pr. Nauk. UE Wroc., Taksonomia 29(469), 109-118.

Kurzawa I, Łuczak A., Wysocki F. 2017. Zastosowanie metod taksonomicznych i ekonometrycznych w wielowymiarowej analizie poziomu życia mieszkańców powiatów w Polsce. Pr. Nauk. UE Wroc., Taksonomia 28(468), 127-137.

Metody i narzędzia badania efektywności aktywnej polityki rynku pracy. 2012. Red. M. Maksim, Z. Wiśniewski. Warszawa, Centrum Rozwoju Zasobów Ludzkich,.

Młodak A. 2006. Analiza taksonomiczna w statystyce regionalnej. Warszawa, Difin, 29-30.

Nowak E. 1990. Metody taksonomiczne w klasyfikacji obiektów społeczno-gospodarczych. Warszawa, PWE, 28-33, 31.

Panek T. 2009. Statystyczne metody wielowymiarowej analizy porównawczej. Warszawa, SGH, 21.

Pociecha J., Podolec B., Sokołowski A., Zając K. 1988. Metody taksonomiczne w badaniach społeczno-ekonomicznych. Warszawa, PWN, 141.

Reichelt A. 2007. Regionalne zróżnicowanie efektywności aktywnych programów rynku pracy w Polsce. Ruch Praw. Ekon. Socjol. 69(3), 153-170.

Rejestr instytucji szkoleniowych, www.ris.praca.gov.pl, dostęp: 20.09.2018.

Ustawa o promocji zatrudnienia i instytucjach rynku pracy z dnia 20 kwietnia 2004 r. DzU z 2017 r., poz. 1065, Załącznik do obwieszczenia Marszałka Sejmu Rzeczypospolitej Polskiej z dnia 26 maja $2017 \mathrm{r}$.

\begin{abstract}
Streszczenie. Powiatowe urzędy pracy (PUP), stosując aktywne formy aktywizacji osób bezrobotnych, starają się przywrócić je na otwarty rynek pracy. Każdy PUP posiada w swoim pakiecie działań tzw. aktywne formy przeciwdziałania bezrobociu. Należą do nich m.in.: staże, szkolenia, prace interwencyjne, roboty publiczne, dofinansowanie podejmowania działalności gospodarczej, refundacja kosztów wyposażenia i doposażenia stanowiska pracy. Wprowadzając na rynek pracy osoby bezrobotne, urząd wykorzystuje jedną lub kilka ww. form aktywizacji. Działania PUP w zakresie aktywizacji klientów podlegają corocznej ocenie. Podstawowym problemem osób nadzorujących rezultaty urzędów pracy na poziomie powiatu, regionu i kraju jest odpowiedź na pytanie, jakie czynniki mogą wpływać na efektywność PUP-ów. W artykule podjęto próbę zidentyfikowania prawidłowości w zakresie współzależności pomiędzy poziomem wskaźnika efektywności zatrudnieniowej, uzyskiwanej w powiatowych urzędach pracy, a czynnikami charakteryzującymi sytuację społeczno-gospodarczą na terenie ich funkcjonowania. Badanie przeprowadzono na podstawie danych z 2016 roku i objęto nim wszystkie PUP-y.
\end{abstract}

Artykuł opracowano w ramach projektu, pt.: „Wypracowanie metodologii $i$ wdrożenie monitorowania efektywności zatrudnieniowej podstawowych form aktywizacji zawodowej bezrobotnych w okresie dłuższym niż 12 miesięcy od zakończenia działań urzędu pracy”, wykonywanego przez Stowarzyszenie Czas Przestrzeń Tożsamość. Projekt wdrożeniowy został dofinansowany ze środków UE z Europejskiego Funduszu Społecznego w ramach programu operacyjnego „Wiedza, edukacja, rozwój” oś priorytetowa: II. Efektywne polityki publiczne dla rynku pracy, gospodarki i edukacji, działanie 2.4: Modernizacja publicznych i niepublicznych służb zatrudnienia oraz lepsze dostosowanie ich do potrzeb rynku pracy). 